\title{
[ARTIGO RETRATADO] A review of recent pediatric research published in Brazilian indexed journals
}

\section{Uma revisão sobre a pesquisa em pediatria recentemente publicada em revistas indexadas brasileiras}

\author{
Maurício Rocha-e-Silva'; Ariane Maris Gomes"' \\ 'MD, PhD. Editor, Hospital das Clínicas (HC), Faculdade de Medicina, Universidade de São Paulo (FMUSP), \\ São Paulo, Brazil \\ "BA. Editorial assistant. Hospital das Clínicas (HC), Faculdade de Medicina, Universidade de São Paulo \\ (FMUSP), São Paulo, Brazil
}

\begin{abstract}
Notice is hereby given of the retraction of the article specified below. This retraction is the free initiative of the authors of the said article. The authors declare that this article constitutes reportage on recently published articles appeared in the Brazilian scientific press and therefore contains no newly published results. It was written for the information of readers of Sao Paulo Medical J ournal. It is retracted because as a consequence of an honest error, it was not prepared in observance of good practices for reviewing of previously published literature. The retraction is formally approved by the Editors of Sao Paulo Medical Journal.
\end{abstract}

Retracted article: Silva MR; Gomes AM. A review of recent pediatric research published in Brazilian indexed journals. Sao Paulo Med. J. 2012; 130(5): 318-329. doi: 10.1590/S1516-31802012000500009.

Sao Paulo, August $2^{\text {nd }}, 2013$

Authors: Mauricio Rocha e Silva | Ariane Maris Gomes

\section{Paulo Manuel Pego Fernandes \\ Editor, São Paulo Medical J ournal}

\begin{abstract}
Os autores do artigo especificado declaram que retratam o mesmo por sua livre e espontânea vontade. Os autores declaram que este artigo constitui uma reportagem sobre artigos recentemente publicados na imprensa científica brasileira, de modo que não contem resultados científicos novos, com a finalidade específica de informar os leitores do São Paulo Medical J ournal. O artigo é retratado porque, em virtude de um erro honesto, não foram observadas boas práticas para a escrita de uma revisão da literatura anteriormente publicada. Esta retratação é formalmente aceita pelos Editores do São Paulo Medical Journal.
\end{abstract}

Artigo retratado: Silva MR; Gomes AM. A review of recent pediatric research published in Brazilian indexed journals. Sao Paulo Med. J. 2012; 130(5):318-329. doi: 10.1590/S1516-31802012000500009.

Sao Paulo, 2 de agosto de 2013

Authors: Mauricio Rocha e Silva | Ariane Maris Gomes 


\title{
A review of recent pediatric research published in Brazilian indexed journals
}

\section{Uma revisão sobre a pesquisa em pediatria recentemente publicada er revisté indexadas brasileiras}

\author{
Maurício Rocha-e-Silva', Ariane Maris Gomes"
}

Hospital das Clínicas (HC), Faculdade de Medicina da Universidade de São Paulo (FMUSP), São Paulo Brazil

'MD, PhD. Editor, Hospital das Clínicas (HC) Faculdade de Medicina, Universidade de São Paulo (FMUSP), São Paulo, Brazil.

"BA. Editorial assistant. Hospital das Clínicas (HC), Faculdade de Medicina, Universidade de São Paulo (FMUSP), São Paulo, Brazil.

\section{KEY WORDS:}

Pediatrics.

Infectious disease medicine.

Pathology.

Dentistry.

Epidemiology

PALAVRAS-CHAVE:

Pediatria.

Infectologia.

Patologia.

Odontologia

Epidemiologia.

\section{ABSTRACT}

This review surveys articles appertaining to the ger field of pea trics that have been published in Brazilian scientific periodicals over recent years. Its ain pu. ose was to bring to the attention of the readership of the São Paulo Medical Journal original contributions $m$ specialty and non-specialty journals. We hope that this can be seen as a general s sinntific update for the readers. We have covered articles appearing in Brazilian ISI-indexed journals, follon $\mathrm{Tg}$ ary nearch.

\section{RESUMO}

Esta revisão cobre artigos pertence tes ac campo ral de pediatria publicados em revistas científicas brasileiras nos últimos anos. Seu incipal jetr. chamar a atenção dos leitores de São Paulo Medical Journal para contribuições oriainár. v vistas especializadas e não especializadas. Oferecemos esta coletânea como uma atualizac scientífica n geral para os leitores. Foram cobertos artigos publicados em revistas brasileiras indexar $\mathrm{ISI}$, após uma busca PubMed.

\section{INTRODUCTIC}

Brazilian medical jo. als, rether multidisciplinary or specialty, have seen an increase in the quality ar volu ze of pus shed original science. This is due to the enhanced visibility induced by the iELO sllect 1 and by the very large increase in Brazilian journals accepted by and indexed in . ISI-Thomson Journal of Citation Reports (JCR). This review catalogues and summarizes pediatr ${ }^{-}$esearch papers appearing in clinical and surgical JCR journals in 2010 and

The criteria observed for selecting articles were generally based on the new concept of continuc sly variable rating, in which articles are evaluated with regard to citations, in comparison with ther articles cited in the same journal. ${ }^{1}$

\section{METHOD}

rubMed search was conducted for all Brazilian journals registered in the JCR database, using children" or "child" as the keyword and limiting the search to the years 2010 and 2011. All articles representing other than original research were manually excluded. Articles published in J Pediatria (Rio de Janeiro) were limited to the most frequently cited in that collection.

\section{GENERAL REVIEW}

\section{Infectious diseases}

1.1. Aids-related research. Contri et al. ${ }^{2}$ described nutritional status, body composition and lipid profile in HIV-infected children and adolescents receiving protease inhibitors. Costa et al. ${ }^{3}$ used delayed-type hypersensitivity skin tests to evaluate in vivo cell-mediated immunity to common antigens in HIV-1-infected pediatric patients. Cruz et al. ${ }^{4}$ analyzed how immunological changes in HIV-infected children interfere in atopy determinants. de Sousa Paiva et al. ${ }^{5}$ analyzed non-verbal mother-child communication under conditions of maternal HIV. Gonçalves et al. ${ }^{6}$ determined prevalence of vertical HIV-1 transmission in the western region of the state of São Paulo. Guimarães 
et al. ${ }^{7}$ reported findings from the first national sample of psychiatric patients about lifetime practice of unsafe sex and associated factors. Machado et al. ${ }^{8}$ characterized urinary excretion of human polyomaviruses in human HIV-infected children and adolescents. Silva et al. ${ }^{9}$ investigated the evolution of children with vertically transmitted HIV/AIDS. Sitoe et al. ${ }^{10}$ studied samples from Mozambique by means of ELISA, using serum samples from 150 pregnant women and six cerebrospinal fluid (CSF) samples from AIDS patients with encephalitis. Tremeschin et al. ${ }^{11}$ reported on nutritional and metabolic alterations among pediatric patients continuously exposed to highly active antiretroviral therapy (HART). Werner et al. ${ }^{12}$ described the lipid profile, body shape changes and cardiovascular risk factors in children and adolescents infected with HIV/AIDS who were receiving highly active antiretroviral therapy.

1.2. Gastrointestinal tract. Borges et al. ${ }^{13}$ evaluated Rotavirus genotypes circulating in Goiânia, Brazil. El Khoury et al. ${ }^{14}$ projected the effectiveness of the RV5 rotavirus vaccine RotaTeq in terms of the percentage reduction in rotavirus gastroenteritisrelated hospitalizations among children less than five years of age in four Brazilian regions (Goiania, Porto Alegre, Salvador and São Paulo). Morillo et al. ${ }^{15}$ reported the results from a five-year surveillance study on rotavirus strains in children under the age of five years with acute gastroenteritis at day care centers in the state of São Paulo, Brazil. Vieira et al. ${ }^{16}$ described the incidence and disease burden of rotavirus diarrhea in two cohorts of 25 children (Rotarix vaccinated and unvaccinated) under one vear of age, enrolled from a low-income residential area in no neast ern Brazil. Silva et al. ${ }^{17}$ investigated Group A rotavir in fec samples from suspected children seen within the public th system of the state of Pernambuco. Gonçalves et al. ${ }^{18}$ investı gated the prevalence of intestinal parasites in 1 dren who attended two daycare centers maintained by he munic ${ }_{1}$ lity of Uberlândia, state of Minas Gerais, Brazil. \& va et al. ${ }^{19}$ a lyzed the prevalence and intensity of infection by $A$. ris lur ricoides by means of a cross-sectional stud among $>0$ children (1-12 years of age) living in the muni pality i Tu ord, Maranhão, Brazil. Jure et al. ${ }^{20}$ studied the ant in susce tibility patterns of 60 strains of Salmonella sp. 1. 'ated n..... children with gastroenteritis and/or extra testinal a nlications. Machado et al. ${ }^{21}$ evaluated the usef in of Western blot (WB) analysis as a diagnostic tool for congenita roplasmosis in 215 newborn infants. Nakano al. examined the antimicrobial resistance profile and the revale ece ecistance genes in Bacteroides spp. and Parabactero "chistasonis strains isolated from children's intestinal microbiota. -ebs et al. ${ }^{23}$ estimated the prevalence of anti-hepa 'tis (anti-HAV) antibodies in 465 serum samples from 1 v ar-old children and adolescents obtained at two clinical pathol $\mathrm{v}$ laboratories in the city of Porto Alegre, southern Brazil, and compared their findings with those from a study carried out in the 1990s. Bertolini et al. ${ }^{24}$ investigated whether hepatitis B virus (HBV) mutants circulate in the southwestern region of the state of Paraná, Brazil, by analyzing samples from 25 children who received immunoprophylaxis but cre born HBV carrier mothers. Livramento et al. ${ }^{25}$ determ led the anti HBs antibody levels among 371 children and ado cents wh had received a complete vaccination cov . hepans $\mathrm{B}$. Carrilho et al. ${ }^{26}$ performed a national sury to update patocellular carcinoma epidemiology in Brazil and termines he clinical and epidemiological profiles of patients in $d_{\llcorner.}$." thrazilian regions. Colli et al. ${ }^{27}$ investigated 1 ocu nce of anti-Toxocara spp. antibodies in children and ad er ents and the variables that may be involved, as wel' s environn. ntal contamination by Toxocara spp. eggs, in urb re ation areas of the northern-central mesoregion, state of Paraná, Bra ${ }^{1}$ Espinoza et al. ${ }^{28}$ assessed the seroprevalence human toxocariasis among 303 subjects (adults and children, in th dean communities from the Northeast of Lima, Peru agoso et al..$^{29}$ evaluated the frequency of anti-Toxc ra a tibodic in serum from 391 seven-year-old children endin clen ary school in Vitória, Espírito Santo, Brazil, nd a lated these antibodies with sociodemographic facto s, presence o ntestinal helminths, blood eosinophil numbo s, pa ' 'istory of allergy or asthma and clinical manifestations of helminth s. ctions. Roldan et al. ${ }^{30}$ determined the seroprevalen $?$ of infection by Toxocara in the general population of the A azonir city of Yurimaguas, Peru.

1.3 Respiratory system. Paulis et al. ${ }^{31}$ compared the severity o. single respiratory syncytial virus infections with that of - ifections through a historical cohort study, including 176 hospitalized infants with acute single respiratory syncytial virus infection. Debur et al. ${ }^{32}$ endeavored to identify human metapneumovirus as the etiological agent of acute respiratory infections (ARIs) among in and outpatients in the city of Curitiba, southern Brazil, and to describe clinical data on human metapneumovirus subtyping through a retrospective study conducted on 1,572 respiratory samples. Pilger et al. ${ }^{33}$ studied occurrences of human metapneumovirus and human bocavirus in the Porto Alegre metropolitan area, by evaluating children with suspected lower respiratory tract infection. Rodrigues et al. ${ }^{34}$ evaluated the trend of pneumonia mortality among Brazilian children aged four years and younger from 1991 to 2007, through a retrospective study based on the database of the Information Technology Department of the Brazilian Unified Health System (DATASUS). Simbalista et al. ${ }^{35}$ described the evolution and outcomes of children hospitalized with community-acquired pneumonia who were receiving penicillin. Luiz et al. ${ }^{36}$ evaluated the presence of human adenoviruses, which is a major cause of acute respiratory diseases, gastroenteritis, conjunctivitis and urinary infections, in 468 nasopharyngeal aspirate samples collected from children with acute respiratory disease at a tertiary hospital in Uberlândia, Brazil. Stroparo et al. ${ }^{37}$ analyzed the sensitivity and specificity of 
the laboratory diagnosis methods available, comparing antigen detection by means of the indirect immunofluorescence assay and a specific nested polymerase chain reaction (PCR), for detecting adenovirus in 381 respiratory samples collected from pediatric patients admitted to hospital with acute respiratory disease. Two other papers come under this heading. Paula et al. ${ }^{38}$ collected 532 nasopharyngeal aspirates (NPAs) over a nine-year period from children at a tertiary hospital in the state of Minas Gerais and tested them for human rhinovirus RNA using the reverse transcription-polymerase chain reaction (RT-PCR). Moretti et al. ${ }^{39}$ conducted a prospective cohort study to evaluate the impact of two definitions used as epidemiological tools, in adults and children, during the influenza A H1N1 epidemic: influenza-like illness definition (coughing + temperature $\geq 38^{\circ} \mathrm{C}$ ) in period 1 , and the definition of severe acute respiratory infection (coughing + temperature $\geq 38^{\circ} \mathrm{C}$ and dyspnea) in period 2 .

1.4. Chagas disease. Carvalho et $\mathrm{al}^{40}$ conducted two serological surveys to evaluate the effectiveness of Chagas disease vector control in the state of São Paulo. The first (1968-1970) evaluated schoolchildren living in all municipalities of the state of São Paulo. The second (1973-1983) involved schoolchil dren in municipalities with high trypanosomiasis prevale e. Ostermayer et al. ${ }^{41}$ surveyed the seroprevalence of Chag disease among 104,954 Brazilian children ( $\leq 5$ years of age' $n$ rur ${ }^{\prime}$ areas. Rassi and Rezende ${ }^{42}$ studied the esophagus an colon of 94 pediatric patients with acute Chagas disease, through c. tition and radiological examination of the esor agus. ntestina transit was assessed in 59 patients (56.7\%).

1.5. Herpesvirus. Magalhães et $\mathrm{al}^{43}$ assessea prevalence of human herpesvirus-7 (HHV-7) in 141 serum san ${ }_{1}$ from children less than four years of age anthematic disease. Magalhães et al. ${ }^{44}$ used a nested mu plex polyn rase chain reaction (PCR) to diagnose human her esvirus $6 \mathrm{~B} p$ mary infection, differentiate it from infections cause whum herpesvirus-6A and compare it to antibod avidity ts, and found that the PCR technique was not suital for d gno no primary infection by HHV-6B in children with vanthema c disease and should not substitute the immuno, orescen... dssay (IFA).

1.6. Leishm ia. Carran. Tamayo et al. ${ }^{45}$ aimed to confirm suspected aute $\mathrm{nth}$. ous cases of visceral leishmaniasis among individuals in Brasilia, throu. a retrospective review of the surveillance data and $1 \mathrm{ml}$ records of reported cases. Fraga et al. ${ }^{46}$ reported on the us of PCP ${ }_{1}$ inheral blood samples to diagnose leishmaniasis am children in Mato Grosso do Sul, Brazil.

1.7. Schis omiasis. Palmeira et al. ${ }^{47}$ determined the occurrence te ory asoma mansoni among 690 students (7-15 years of age) in tw $r$ nicipalities, located in the Mundau and Paraíba river basins. Peren et al. ${ }^{48}$ evaluated school-age children (6-15 years) in the schistosomiasis endemic area of Pernambuco, both as a target group for and an indicator of schistosomiasis control in the community.
1.8. Tuberculosis. Basta et al. ${ }^{49}$ described the clinical and radiological characteristics of children and adolescents in a population of Surui Indians in Rondônia, Braz , where t. incidence of tuberculosis was 2,500/100,000 inhabi nts (1991-2 2), with about $50 \%$ in children $<15$ years of age. Sa et al. ${ }^{50}$ ar cyzed the

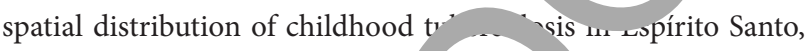
between 2000 and 2007, accordi g to munic al notifications.

1.9. Blastomycosis. Eymael et ${ }^{51}$ evaluat d the effectiveness of different techniques for diagnosing $b_{\text {. }}+{ }_{+}$ystis hominis among 100 children and adults.

1.10. Chlamydi Nis $\mathrm{N}$ i-Dantas et al. ${ }^{52}$ identified Chlamydia trachon tis via the $\mathrm{R}$ versus via the direct fluorescent antibody as y hernts with vernal keratoconjunctivitis.

1.11. Others. Martins -1.53 conducted a study in which the molecular of 63 cryptococcal isolates recovered from the cerebrospinal flu of $\mathrm{m}$ in patients diagnosed in Teresina, Piauí, Brazil, were an. Led. Costa and Façanha ${ }^{54}$ studied blood samples fro chı en wit he aim of identifying dengue virus serotypes in anaus razu Mranzi et al. ${ }^{55}$ described the epidemiological profile e population with a diagnosis of leprosy in the municipality of Ub ba, Minas Gerais, Brazil, through a retrospective study. "miasegen et al..$^{56}$ established the prevalence of human parvovirus im oglobulins G and M (IgG and IgM) antibodies, including correlates of infection, among 273 pregnant women (aged 15-40 ars) attending an antenatal clinic in Nigeria. Gbotosho et al. ${ }^{57}$ looked at the effects of artemisinin-based combination therapies (ACTs) on transmission of Plasmodium falciparum after a policy change instituting the use of combination therapy in an endemic area. Fernandes et al. ${ }^{58}$ evaluated the prevalence and dissemination of carbapenem-resistant and metallo-beta-lactamase-producing Pseudomonas aeruginosa isolated from 56 blood-stream samples collected from 49 patients admitted to a tertiary Pediatric Oncology service. Goud et al..$^{59}$ aimed to determine the prevalence of methicillin-resistant Staphylococcus aureus in the community of Bangalore, southern India.

2. Nutrition. Aprile et al. ${ }^{60}$ described the growth and clinical evolution of 30 very low birth weight infants who were fed during their hospital stay with milk from a human milk bank according to the caloric-protein value, versus 10 who were fed milk from their own mothers. Lins et al. ${ }^{61}$ determined the prevalence of cow's milk protein allergy among 65 children with symptoms attributed to cow's milk intake. Venancio et al. ${ }^{62}$ presented the breastfeeding indicators obtained in the Second Survey on Breastfeeding Prevalence in Brazilian State Capitals and the Federal District and analyzed their evolution from 1999 to 2008. Caetano et al. ${ }^{63}$ assessed the feeding practices and dietary intake of healthy infants in three Brazilian municipalities by means of a prospective study using the food records of seven consecutive days from an intentional sample (quota and weighted sampling) of 179 healthy infants aged between 4 and 12 months who were 
not being exclusively breastfed. Silveira et al. ${ }^{64}$ investigated the association of malnutrition with maternal nutritional status and environmental conditions among children living in substandard settlements (shantytowns) in Maceio, Brazil.

3. Metabolic syndrome. Balaban et al. ${ }^{65}$ investigated whether early weaning constitutes a risk factor for overweight at preschool age, and identified other factors that affect this association, through a case-control study on 366 children aged 2 to 6 years in three Brazilian cities. Nascimento et al. ${ }^{66}$ analyzed the usefulness of the weight gain/height gain ratio from birth to two and three years of age as a predictive risk indicator of excess weight at preschool age, among 409 preschool children (3.2 \pm 0.3 years). Pergher et al. ${ }^{67}$ presented the components of the metabolic syndrome among children and adolescents and discussed how they are assessed in the pediatric population.

4. Neurology. Samelli et al. ${ }^{68}$ developed and analyzed the efficacy of a low-cost screening tool to identify and classify hearing loss in children. A total of 214 children ( $2-10$ years) participated in this study. Schochat et al. ${ }^{69}$ determined the middle latency response (MLR) characteristics (latency and amplitude) in children with central auditory processing disorder, categorized as such by their performance in the central auditory test battery, and the effects of these characteristics after auditory training. Gonçalves et al. ${ }^{70}$ evaluated neurophysiological auditory brainstem responses to clicks and repeated speech stimuli to determine whether they differed between normal children an. children with phonological disorders. Prudente et al. ${ }^{71}$ analyzed the quality of life of mothers of children with cerebral palsy, cc elatec with the evolution of their children's gross motor functic after to months of rehabilitation. An observational, longitudinal stuu, vas carried out in Goiânia, Goiás, Brazil, involving 100 mothers and chı dren with cerebral palsy. Unlu et al. ${ }^{72}$ described the f multilevel botulinum toxin-A injections on the lower extr mities throc $h$ a retrospective study, focusing mainly on gross mo runction ar functional status among 72 cerebral palsy patients. Be $+\mathrm{al}^{73} \mathrm{e}$ uated a retrospective cohort of Wilson's diseas patients $>$ m southern Brazil over a 40-year follow-up period in $v$ at the, clain tu to be the first retrospective description of a populat. n of Wilso disease patients of mainly European continental vin whe were living in southern Brazil. Murphy and S ochat ${ }^{74}$ in vated the ability to learn the generalization of as $\mathrm{c}_{\mathrm{L}}$. ckill of auditory temporal processing (temporal order detection) among ildren with dyslexia. Nunes and Dupas $^{75}$ developed the etical model concerning the experience of families of chil $r^{\prime}$ en with syndrome at preschool and school age using Symbon ' $n$ ' ractionism and Grounded Theory. Olandoski et al. $^{76}$ analvzed the evo. ion of renal function in patients with congenital ne rogenn - dder by reviewing the records of 58 pediatric patients with er do 13 attributes.

5. Psychiatry. 1 ves et al. ${ }^{77}$ evaluated 40 parents of children with autism and 41 healthy controls. All participants were administered the Penn Emotion Recognition Test (ER40) and were genotyped for 5HTTLPR. The authors ${ }^{77}$ assessed facial emotion recognition among 40 parents of children with autism versus 41 controls, and its associations with functional polymorphism of + seroto transporter (5HTTLPR). Pinheiro et al. ${ }^{78}$ described te prevalence of depressive and bipolar spectrum episodes amon 739 father during the antenatal and postnatal periods, ar an montwo atter childbirth. Zappitelli et al. ${ }^{79}$ identified ps niatric diag oses in a sample of 35 children (6-17 years) who had a ast one $p$ ent with bipolar disorder type I. Fávero-Nunes and dos sa evaluated the prevalence of dysphoria/depressi symr in 20 mothers of autistic children and identified correlat $n$ oetween quality of life and the sociodemographic $\mathrm{p}$ ile by apply $\mathrm{g}$ a sociodemographic profile questionnaire, the ${ }^{r}$ azl . version or the Beck Depression Inventory (BDI) and the WHOQO BREF quality-of-life scale. Guimarães et al. ${ }^{7}$ rep tod findings from the first national sample of psychiatric patients latin and ime practice of unsafe sex and associated factors. Lin et evaluated the risks and rates of readmission and eir $\mathrm{p}$ dictors 14 days, one year and five years after discharge r the $\mathrm{p}$ chia population in Taiwan, based on claims from $423 \%$ time hospitalized psychiatric patients who were disc ${ }^{\prime}$ rged in 200 - alum et al. ${ }^{82}$ described the design, methods ar $\operatorname{san}_{1}$ characteristics of the Multidimensional Evaluation and Treatment or vxiety in Children and Adolescents (PROTAIA) proj $\mathrm{t}$, as applied to students between 10 and 17 years of age at all si school selonging to the catchment area of Hospital de Clínicas Port Alegre. A total of 2,457 subjects were screened. Turkiewicz et al. examined the feasibility, acceptability and effectiveness of 1. Aly-based treatment for anorexia nervosa for patients aged 12-17 years in Brazil, through an observational study.

6. Hematology. Fernandes et al. ${ }^{84}$ described the deaths of children with sickle cell disease (SCD) in Minas Gerais, Brazil, who had been followed up at the Hemominas Foundation. Clinical and epidemiological data were abstracted from death certificates, the newborn screening database, individual medical records and interviews with families. Menegassi et al. ${ }^{85}$ investigated hematological variables relating to iron deficiency and food intake in cases of attention-deficit/hyperactivity disorder among 62 children and adolescents (6-15 years old). Sellami et al. ${ }^{86}$ examined the effect of histocompatibility antigen HA-1 disparity on the incidence of both acute and chronic graft-versus-host disease in Tunisian recipients of hematopoietic stem cells. Bortolini and Vitolo ${ }^{87}$ evaluated the prevalence of anemia, iron deficiency and iron deficiency anemia in a cohort of children, through a cohort study nested in a randomized field trial. Children were recruited at birth at the maternity unit of the only public hospital in the city of São Leopoldo, southern Brazil. Reis et al. ${ }^{88}$ conducted a cross-sectional, descriptive and quantitative study as part of a multicenter project, to determine the prevalence of anemia among 121 children aged three to 12 months who were treated at a health service unit in Ribeirão Preto, SP, Brazil. 
7. Cardiology and angiology. Dumaresq et al. ${ }^{89}$ evaluated the metabolic and oxidative effects of sevoflurane and propofol among 20 children aged between one day and 14 years, with acyanotic congenital heart disease, who were scheduled for elective corrective cardiac surgery including cardiopulmonary bypass. They were randomly assigned to two groups: one received total intravenous anesthesia using propofol, and the other received balanced anesthesia using sevoflurane. Tedde et al. ${ }^{90}$ compared bar displacement and complication rates in three retrospective series of mostly pediatric patients operated on by the same surgical team to treat pectus excavatum. Kayiran et al. ${ }^{11}$ described the demographic, clinical and laboratory features of 35 children with Kawasaki disease who were diagnosed and managed in the American Hospital, Istanbul, Turkey. Orlando et al..$^{92}$ analyzed the results from treating patients with deep venous malformations using low doses of ethanol. Vanderlei et al..$^{93}$ compared the autonomic function of 121 obese and eutrophic children (8-12 years) by analyzing heart rate variability. Guimarães et al. ${ }^{94}$ assessed pulmonary function and the prevalence of atopy among 85 school-age children who had presented very low birth weight as infants, and compared those who had bronchopulmonary dysplasia with those who did not. Munhoz et al. ${ }^{95}$ described the clinical an laboratory characteristics of 155 pediatric patients undergoing lo gterm home $\mathrm{O}_{2}$ therapy (53\% male; median age at onset of th rapy: 3.6 years; median duration of therapy: 7 years; median sur val afte start of $\mathrm{O}_{2}$ therapy: 3.4 years). Soeiro et al. ${ }^{96}$ described de ${ }^{0-}$ graphic data, etiology and pulmonary histopathological find. of different diseases from autopsies on 4,710 patient age 1 nge: 1-9 years) with acute respiratory failure.

8. Pediatric oncology. Carrilho et al. ${ }^{26}$ conductea ational survey to update hepatocellular carcinoma epidemiolog $>$ Brazil and determined the clinical and e $>$ logical profiles of patients in different Brazilian regi ns. Cicogn. et al. ${ }^{97}$ aimed to comprehend chemotherapy from $t$ e perspectiv of children and adolescents with cancer. Ten childro and ar escents between eight and 18 years of age c differ ${ }^{+}$phases of chemotherapy, participated in this exp ratory qual ative study. Estrozi and Bacchi $^{98}$ described some nical path logical characteristics of neuroendocrine tumo. of th owuroenteropancreatic tract in Brazilian patien . The stua, vestigated the clinical pathological features of $/ 1$ "razilian gastroenteropancreatic neuroendocrine tumor cases fro all the geographical regions of Brazil. Gualco al. provided clinical pathological characteristics of 1301 ses of cur ric/adolescent lymphomas in patients from differen ${ }_{f}$ graphical regions of Brazil. Pan et al. ${ }^{100}$ characterized hospita tions of children and adolescents with cancer, om +2008 , to describe the clientele that was being follo $d$ in the regional health area of Ribeirão Preto, SP, Brazil. Tama hiro et al. ${ }^{101}$ assessed the clinical and laboratory features that differentiate acute lymphoblastic leukemia from systemic juvenile idiopathic arthritis at disease onset among 102 systemic juvenile idiopathic arthritis patients who were retrospectively evaluated. Vaisman et al. ${ }^{102}$ designed a study to evaluate 65 patients (4-20 years of age) with diff entiatea vroid carcinoma diagnosed before 20 years of ag and to dete nine the factors associated with the response to the nitial ther $p y$.

9. Immunology. Guimarães et al. ${ }^{94}$ punnury function and the prevalence of atopy am ng 85 scho age children who had presented very low birth wo ht as inf ts and compared those who had bronchopulmonary dys $s_{1}$ ". with those who did not. Lins et al. ${ }^{61}$ determin t thr malence of cow's milk protein allergy among 65 hildre w n symptoms attributed to cow's milk intake. Yu-br et al. ${ }^{103}$ ob ined the recombinant group 2 allergen produc ${ }^{+}$of $D$ natophagoides farinae (the Der $\mathrm{f} 2$ gene), which was synthesized by ans of RT-PCR. Sole et al. ${ }^{104}$ identified the $\mathrm{m}$ - linical manifestations, triggers and treatments of severe allers reas an patients who were seen by allergists from July 2008 June 2010 in 15 Latin American countries and Po, agal. Costa al. $^{3}$ used delayed-type hypersensitivity skin + sts to e cua vivo cell-mediated immunity to common antigetı rong HIV-1-infected pediatric patients. Macêdo et al. ${ }^{105}$ investiga. risk factors for type 2 diabetes mellitus in a populaion of 277 children in public schools. A protocol for gathering soc 'emographic data, body mass index, blood pressure, capillary blood glucose and waist circumference was applied.

1. Critical care, trauma and anesthesiology. Carvalho et al. ${ }^{106}$ determined the incidence and risk factors of accidental extubation in a tertiary neonatal intensive care unit through a prospective cohort study that was conducted to determine its incidence density per 100 patient-days among 222 newborns who were receiving assisted ventilation. Costa et al. ${ }^{107}$ used the pediatric risk-of-mortality tool to determine mortality risk factors in tertiary pediatric intensive care units. Vendrusculo et al. ${ }^{108}$ characterized burn accidents in domestic environments and identified the circumstances of accidents affecting children, adults or elderly people who needed supervision or care. Dumaresq et al. ${ }^{89}$ evaluated the metabolic and oxidative effects of sevoflurane and propofol among 20 children aged between one day and 14 years, with acyanotic congenital heart disease, who were scheduled for elective corrective cardiac surgery including cardiopulmonary bypass. Shoroghi et al. ${ }^{109}$ investigated and compared the efficacy of oral midazolam at two different dosages in orange juice, on perioperative hemodynamics and behavioral changes among 90 children who underwent laser skin treatment at a university teaching hospital.

11. Orthopedics. Chen et al. ${ }^{110}$ determined the features of earthquake-related pelvic crush fractures versus non-earthquake fractures by means of digital radiography and multidetector array computed tomography. The frequency of occurrence among children was reported. Chu et al. ${ }^{111}$ compared the features of head traumas caused by the Sichuan earthquake with those of other common head traumas using multidetector computed 
tomography. Occurrences of lesions in children were described. Ribeiro et al. ${ }^{112}$ determined bone quantity by means of ultrasound measurements on the proximal finger phalanges of 1356 healthy Brazilian schoolchildren (age 6-11 years) living in Paraná, Brazil, and compared these values with European populations. Taveira et al. ${ }^{113}$ longitudinally assessed bone mineral density and factors involved in bone remodeling in nine children and adolescents with chronic cholestatic liver disease (Child-Pugh A).

12. Gastroenterology. Castro-Antunes et al. ${ }^{114}$ evaluated the frequencies of the HLA genotypes DQ2 and DQ8 and the alleles $\mathrm{A} 1^{\star} 05, \mathrm{~A} 1^{\star} 0201, \mathrm{~B} 1^{\star} 0201$ and $\mathrm{B} 1^{\star} 0302$ in individuals with celiac disease in Recife, northeastern Brazil. Gonzales et al. ${ }^{115}$ assessed the concentration of fecal elastase-1 (EL-1) in 51 pediatric patients with cystic fibrosis with mutation DeltaF508, through a cross-sectional study. Hong et al. ${ }^{116}$ aimed to develop a decision model based on classification and regression tree analysis for prediction of large esophageal varices in cirrhotic patients.

13. Rheumatology. Hua-Li et al. ${ }^{117}$ explored the characteristics of seasonal distribution and the influences of meteorological factors, including temperature and humidity, on active systemic lupus erythematous through a retrospective analysis on 640 patients living in the city of Zhanjiang, China. Tamashiro et al. ${ }^{101}$ assessed clinical and laboratory features that differentiate acute lymphoblastic leukemia from systemic juvenile idiopathic arthritis at disease onset among 102 systemic juvenile idiopathic arthritis patients who we. retrospectively evaluated.

14. Urology. Dutra et al. ${ }^{118}$ evaluated the prevalence of te acula microlithiasis among pediatric patients with inguinoscr il cond tions. The study prospectively evaluated 1504 children rangin ${ }_{\delta}$ im 1 to 15 years with these conditions. Olandoski et al. ${ }^{76}$ analyzed the evolution of renal function in patients with con neurogenic bladder by reviewing the records of 58 pediatri patients wi regard to the following attributes: gender, age, etiolog of neurogen bladder, reason for referral, medical/surgical manas ent, e odes of treated urinary tract infections, uro namics ${ }^{\top}$ imercaptosuccinic acid (DMSA) scintigraphy, weight, $\mathrm{t}$ ght, b1 od p sure, glomerular filtration rate, microalbuminuria à metaboli acidosis.

15. Drug abuse. Medina Arias an Ferrian analyzed the protective factors that prevented cug use an $o$ the families of children who were attending $C \mathrm{~m}_{\text {. }}$. nity Homes for Family Wellbeing in a small Colombian locality, th. 'igh a quantitative descriptive transversal study, III 56 families constituting the sample. CidMonckton and cdrão ${ }^{12}$ ton verify protective and risk factors within the family clation to drug use among 80 female adolescents, taking into co ideration the interaction patterns developed in $t_{1}$ tamn their degree of adaptability and vulnerability, through ors-sectional and quantitative study.

16. Cystic fibr is. Mattar et al. ${ }^{121}$ compared sweat chloride values obtained by means of quantitative pilocarpine iontophoresis (classic test) with sweat conductivity values obtained using the
Macroduct collection system in patients with and without cystic fibrosis. Stollar et al. ${ }^{122}$ studied correlations between forced expiratory volume in one second (FEV1), chest radio aphy, ch computed tomography, six-minute walk test and shwachman Kulczycki score among 43 pediatric patients with c, tic fibrosi and they tested whether this score was still arm momuring the severity of the disease.

17. Other medical topics. Bousso et al. ${ }^{12}$ - deavored to determine the relationship between the experiences on " nes of children with a life-threatening disease a trim ' ${ }^{*}$ rion, illnesses and life histories, based on oral histrry. Dut $\epsilon$ al. ${ }^{124}$ aimed to test five microsatellite markers (D7S' 10, D7S48, D7S613, D7S2476 and D7S489_A) for diagnosin (W. ms-Beuren syndrome, in order to determine the size and parental o rin of microdeletion. Eren et al. ${ }^{125}$ presented th necial clinical and laboratory features of 294 cases of mushroo pois an a Turkish university hospital (Cumhuriyet). Ferrer et described the causes of admission to the public $\mathrm{h}$.th $\mathrm{s}$, tem an ng children from zero to nine years of age in t e city s sao alo during the years 2002 to 2006 and compa d the esults with other Brazilian data. Fomin et al. ${ }^{127}$ desc sed clinical. d laboratory data and phenotypic characteris $s$ re $n g$ to patients with DiGeorge syndrome. Luque et al. ${ }^{128}$ valuated car $>r$ at-risk newborns under follow-up in their first year $f$ life through the Growing Happily Program, developed in a ci in the rate of São Paulo, Brazil. Nascimento et al. ${ }^{129}$ aimed to 'ders' ad how mothers regard their children's pain management by th nursing team in the late postoperative phase of cardiac sur\%. Empirical data collection was carried out through semi-structured interviews with 17 mothers who accompanied their children. Noma et al. ${ }^{130}$ endeavored to identify barriers to attendance for eye examinations among schoolchildren. Noreña Peña and Cibanal Juan ${ }^{131}$ described the experience of children in their interactions with nursing professionals while in hospital, through a qualitative study supported by the critical incident technique. Wang et al. ${ }^{132}$ reported the incidence and recurrence of acute otitis media in Taiwan's pediatric population and estimated that the annual incidence rate was 64.5 cases per 1,000 children. Zambrano-Sanchez et al. ${ }^{133}$ identified the frequency of risk factors for learning disabilities among children of low socioeconomic level (5.5 years of age and total intelligence quotient of 99 on average) in Mexico City, who were studied by means of the Wechsler, Bender-Gestalt and human drawing tests.

18. Dentistry. Areias et al. ${ }^{134}$ characterized the environmental and host factors associated with dental caries among Portuguese children with and without Down syndrome, through a siblingmatched, population-based, cross-sectional survey. Carrillo et al. ${ }^{135}$ characterized the population seen at the dentistry unit of the hematology-oncology service of a tertiary medical center in São Paulo. Lima et al. ${ }^{136}$ aimed to comprehend the experiences of family members regarding their children's oral healthcare. Motta 
et al. ${ }^{137}$ determined whether there was any correlation between halitosis and mouth breathing among 55 children between 3 and 14 years of age, divided into two groups (nasal and mouth breathing). Perinetti et al. ${ }^{138}$ investigated whether malocclusion traits correlated with body posture alterations among 122 young subjects, in order to determine possible clinical applications. Souza et al. ${ }^{139}$ investigated dental abnormalities and oral health condition among pediatric patients suffering from hypophosphatemic rickets through a prospective study on oral conditions. Cunha Filho et al. ${ }^{140}$ evaluated the effects of L-alanyl-glutamine (L-AlaGln) pretreatment on oxidative stress, glycemia control and inflammatory response among 30 boys (age range: 2-10 years) who were scheduled to undergo routine palatoplasty. The patients were randomly assigned to saline control or L-Ala-Gln groups.

\section{CONCLUSIONS}

This study demonstrates that the volume and quality of pediatric research published in Brazilian journals has increased perceptibly over this period.

\section{REFERENCES}

1. Rocha e Silva M. Continuously variable rating: a new, simple id logical procedure to evaluate original scientific publications slinics (Sao Paulo). 2011;66(12):2099-104.

2. Contri PV, Berchielli EM, Tremeschin MH, et al. Nutri nal st us and lipid profile of HIV-positive children and adolescents ing antiretroviral therapy. Clinics (Sao Paulo). 2011;66) .997- 02.

3. Costa NM, Albuquerque M, Lins JB, Alvares- ujor JT/ efani M. Resposta de testes de hipersensibilidade tardia rando PPD e outros antígenos em crianças e adolescentes saudáveis t fectados pelo HIV-1 e vacinados com BCG [Del hypersensitivity skin test responses to PPD and other itigens amo g BCG-vaccinated HIV-1-infected and healthy childre and adolesc its]. Rev Soc Bras Med Trop. 2011;44(5):542-5.

4. Cruz CR, Carvalho VO, Sa os RV, et Laboratorial atopy markers in children with human it nunoG incier y virus. Mem Inst Oswaldo Cruz. 2010;105(3):293-8.

5. de Sousa Paiva S, Ivão in., áliuca LM, de Almeida PC. Comunicação áo-verbal m. fillho na vigência do HIV materno em ambiente f per. ental [Non-verbal mother-child communication in conditions of materna. UV in an experimental environment]. Rev Lat Am F rern gem. 2010;18(1):41-7.

6. G rçalves Th ni C, Ribeiro AA, et al. Transmissão vertical do HIV-1 na $\wedge$ ã seste do Estado de São Paulo [Vertical transmission of HIV1 in the $v$ rern region of the State of São Paulo]. Rev Soc Bras Med mor $11 \cdot 44(1): 4-7$.

7. G' narães MD, McKinnon K, Campos LN, Melo AP, Wainberg M. C nportamento de risco para o HIV de pacientes psiquiátricos: uma amostra de pacientes brasileiros [HIV risk behavior of psychiatric patients with mental illness: a sample of Brazilian patients]. Rev Bras
Psiquiatr. 2010;32(4):351-60.

8. Machado DM, Fink MC, Pannuti CS, et al. Human nolyomaviruses JC and BK in the urine of Brazilian children a $a$ adolesc ts vertically infected by HIV. Mem Inst Oswaldo Cruz. 2 11;106(8):931-

9. Silva MJ, Mendes Wda S, Gama ME, Chein M Veras DS. P fil clínicolaboratorial de crianças vivendo c MIDS crin ama cidade do Nordeste brasileiro [Clinical anc aboratory pi fle of children living

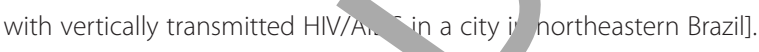
Rev Soc Bras Med Trop. 2010;43(1):32-5.

10. Sitoe SP, Rafael B, Meirelt LR, $/$ n HF, Thompson R. Descrição preliminar da ocorrência o ecção pelo HIV e toxoplasmose em mulheres $c$ vidas em $\lambda$ cambique [Preliminary report of HIV and Toxc asim rondii occurrence in pregnant women from Mozambique]. Rev Inst Mi Trop Sao Paulo. 2010;52(6):291-5.

11. Tremesc $M M H$, Sartorelli DS, Cervi MC, et al. Avaliação nutricional e do perfil lipía o em ran, eadolescentes infectadas pelo HIV tratadas com terapia retroviral de alta potência [Nutritional assessment and pid p file in $H_{1}$ infected children and adolescents treated with highly active ntire ral therapy]. Rev Soc Bras Med Trop. 2011;44(3):274-81.

12. ner ML, Pone MV, Fonseca VM, Chaves CR. Lipodystrophy syndi and cardiovascular risk factors in children and adolescents infected with HIV/AIDS receiving highly active antiretroviral therapy. Sodiatr (Rio J). 2010;86(1):27-32.

13. Borges AM, Dias e Souza M, Fiaccadori FS, Cardoso DD. Monitoring the circulation of rotavirus among children after the introduction of the Rotarix vaccine in Goiânia, Brazil. Mem Inst Oswaldo Cruz. 2011;106(4):499-501.

14. El Khoury AC, Mast TC, Ciarlet M, et al. Projecting the effectiveness of RotaTeq" against rotavirus-related hospitalisations in Brazil. Mem Inst Oswaldo Cruz. 2011;106(5):541-5.

15. Morillo SG, Luchs A, Cilli A, et al. Characterization of rotavirus strains from day care centers: pre - and post-rotavirus vaccine era. J Pediatr (Rio J). 2010;86(2):155-8.

16. Vieira SC, Gurgel RQ, Kirby A, et al. Acute diarrhoea in a community cohort of children who received an oral rotavirus vaccine in Northeast Brazil. Mem Inst Oswaldo Cruz. 2011;106(3):330-4.

17. Silva ML, Souza JR, Melo MM. Prevalência de rotavírus em crianças atendidas na rede pública de saúde do estado de Pernambuco [Rotavirus prevalence in infants and children in the public healthcare system of the state of Pernambuco]. Rev Soc Bras Med Trop. 2010;43(5):548-51.

18. Gonçalves AL, Belizário TL, Pimentel Jde B, Penatti MP, Pedroso Rdos S. Prevalência de parasitoses intestinais em crianças institucionalizadas na região de Uberlândia, Estado de Minas Gerais [Prevalence of intestinal parasites in preschool children in the region of Uberlândia, State of Minas Gerais, Brazil]. Rev Soc Bras Med Trop. 2011;44(2):191-3.

19. Silva JC, Furtado LF, Ferro TC, et al. Parasitismo por Ascaris lumbricoides e seus aspectos epidemiológios em crianças do Estado do Maranhão [Parasitism due to Ascaris lumbricoides and its epidemiological characteristics among children in the State of Maranhão]. Rev Soc Bras Med Trop. 2011;44(1):100-2.

20. Jure MA, Aulet O, Trejo A, Castillo M. Salmonella enterica serovar Oranienburg produtora de B-lactamase de espectro extendido 
(grupo CTX-M-2) em um hospital pediátrico de Tucumán, Argentina [Extended-spectrum beta-lactamase-producing Salmonella enterica serovar Oranienburg (CTX-M-2 group) in a pediatric hospital in Tucumán, Argentina]. Rev Soc Bras Med Trop. 2010;43(2):121-4.

21. Machado AS, Andrade GM, Januário JN, et al. IgG and IgM western blot assay for diagnosis of congenital toxoplasmosis. Mem Inst Oswaldo Cruz. 2010;105(6):757-61.

22. Nakano V, Nascimento e Silva A, Merino VR, Wexler HM, Avila-Campos MJ. Antimicrobial resistance and prevalence of resistance genes in intestinal Bacteroidales strains. Clinics (Sao Paulo). 2011;66(4):543-7.

23. Krebs LS, Ranieri TM, Kieling CO, Ferreira CT, Silveira TR. Shifting susceptibility to hepatitis A among children and adolescents over the past decade. J Pediatr (Rio J). 2011;87(3):213-8.

24. Bertolini DA, Ribeiro PC, Lemos MF, Saraceni CP, Pinho JR. Caracterização de uma cepa de hepatite por vírus B no sudoeste do Paraná, Brasil, apresentando mutações previamente associadas à resistência anti-HBs [Characterization of a Hepatitis B virus strain in southwestern Paraná, Brazil, presenting mutations previously associated with anti-HBs Resistance]. Rev Inst Med Trop Sao Paulo. 2010;52(1):25-30.

25. Livramento A, Cordova CM, Scaraveli NG, et al. Níveis de anti-HBs entre crianças e adolescentes com o esquema completo de imunização contra o vírus da hepatite B. Um estudo transversal em Blumenau, Estado de Santa Catarina, 2007-2008 [Anti-HBs levels among children and adolescents with complete immunization schedule against hepatitis B virus. A cross-sectional study in Blumenau, State of Sar. Catarina, Brazil, 2007-2008]. Rev Soc Bras Med Trop. 2011;44(4):412-5.

26. Carrilho FJ, Kikuchi L, Branco F, et al. Clinical and epidem rogico aspects of hepatocellular carcinoma in Brazil. Clinics Paul 2010;65(12):1285-90.

27. Colli CM, Rubinsky-Elefant G, Paludo ML, et al. Avaliação sorológica, clínica e epidemiológica da toxocaríase em ár anas do sul do Brasil [Serological, clinical and epidem rogical evar tion of toxocariasis in urban areas of south Brazil]. vv Inst Med 7 sp Sao Paulo. 2010;52(2):69-74.

28. Espinoza YA, Huapaya PE, Roldán WH, $€$ al. Soropr - lência da toxocaríase humana em três comunidades ar nas dow Norde w de Lima, Peru [Seroprevalence of human toxocariasis. Andean ce imunities from the Northeast of Lima, Peru]. Rev Inst in Trop Sun u ulo. 2010;52(1):31-6.

29. Fragoso RP, Monteiro N , Lemos Elm, Dereira FE. Anticorpos antiToxocara em criança aa das na escola fundamental em Vitória, Estado do Espírito Santo: prev ncia e fatores associados [AntiToxocara antib ares etected in children attending elementary school in V oria, St? associated fact -1 ev Soc Bras Med Trop. 2011;44(4):461-6.

30. Roldan WH, Caven YA, Espinoza YA, Jimenez S, Gutierrez CA. Xocarn humana: inquérito soroepidemiológico na cidade a a onica de Yurimaguas, Peru [Human toxocariasis: a seroepidem logical survey in the Amazonian city of Yurimaguas, Peru]. Rev Inst Med Trop São Paulo. 2010;52(1):37-42.

31. Paulis M, Gilio AE, Ferraro AA, et al. Gravidade das coinfecções virais em lactentes hospitalizados com infecção por vírus sincicial respiratório [Severity of viral coinfection in hospitalized infants with resniratory syncytial virus infection]. J Pediatr (Rio J). 2011;87(4):307 3.

32. Debur MC, Vidal LRR, Stroparo E, et al. Imp t of humar metapneumovirus infection on in and outpatients for years 2008 2008 in Southern Brazil. Mem Inst Oswaldo Cr. 105 (0),.nu-10-8.

33. Pilger DA, Cantarelli WV, Amantea SL, Leis er-Segal S. L tection of human bocavirus and human metapneum rus by res time PCR from patients with respiratory symntoms in Sou $r$ Brazil. Mem Inst Oswaldo Cruz. 2011;106(1):56-6

34. Rodrigues FE, Tatto RB, Vauchir-ki L, et a W talidade por pneumonia em crianças brasileiras até anos de idc [Pneumonia mortality in Brazilian children agr 4 , rs and younger]. J Pediatr (Rio J). 2011;87(2):111-4.

35. Simbalista R, Ara Mascimento-Carvalho CM. Outcome of children hospitalize with ce im. ity-acquired pneumonia treated with aqueous penicillii clinics (Sao Paulo). 2011;66(1):95-100.

36. Luiz LN, ste G, Yoko. wa J, et al. Molecular characterization of adf oviruse irom ildren presenting with acute respiratory disf se in lândia, Minas Gerais, Brazil, and detection of an isolate netically relà to feline adenovirus. Mem Inst Oswaldo Cruz. $2010,5(5): 712-6$

7. Stroparo L, yz CR, Debur MC, et al. Infecção respiratória aguda por -denovirus: comparação dos métodos de PCR e imunofluorescência indiret para o seu diagnóstico e dados clínicos dos pacientes infe ados [Adenovirus respiratory infection: significant increase in a. gnosis using PCR comparing with antigen detection and culture methods]. Rev Inst Med Trop São Paulo. 2010;52(6):317-21.

38. Paula NT, Carneiro BM, Yokosawa J, et al. Human rhinovirus in the lower respiratory tract infections of young children and the possible involvement of a secondary respiratory viral agent. Mem Inst Oswaldo Cruz. 2011;106(3):316-21.

39. Moretti ML, Sinkoc V, Cardoso LG, et al. Lições aprendidas pelo programa de vigilância epidemiológica, durante a epidemia pelo vírus da influenza A (H1N1), em um hospital universitário na região sudeste do Brasil [Lessons from the epidemiological surveillance program, during the influenza $A(\mathrm{H} 1 \mathrm{~N} 1)$ virus epidemic, in a reference university hospital of Southeastern Brazil]. Rev Soc Bras Med Trop. 2011;44(4):405-11.

40. Carvalho ME, Silva RA, Wanderley DMV, Barata JMS. Programa de Controle da Doença de Chagas no Estado de São Paulo: aspectos sorológicos e entomológicos de inquéritos entre escolares de ensino fundamental [Chagas disease Control Program in the State of São Paulo, Brazil: serological and entomological aspects of primary schoolchildren surveys]. Rev Soc Bras Med Trop. 2011;44(supl 2):95-106.

41. Ostermayer AL, Passos ADC, Silveira AC, et al. $O$ inquérito nacional de soroprevalência de avaliação do controle da doença de Chagas no Brasil (2001-2008) [The national survey of seroprevalence for evaluation of the control of Chagas disease in Brazil (2001-2008)]. Rev Soc Bras Med Trop. 2011;44(supl 2):108-21.

42. Rassi A, Rezende JM. Estudo clinic-radiológico do esôfago e dos 
cólons na fase aguda da doença de Chagas com relato de três casos de remissão espontânea de aperistalse do esôfago do grupo I [Clinical and radiological evaluation of the esophagus and colon in the acute phase of Chagas disease with Report of three cases of spontaneous remission of esophageal group I aperistalsis]. Rev Soc Bras Med Trop. 2011:44(1):70-5.

43. Magalhães IM, Martins RVN, Vianna RO, et al. Detection of human herpesvirus 7 infection in young children presenting with exanthema subitum. Mem Inst Oswaldo Cruz. 2011;106(3):371-3.

44. Magalhães IM, Martins RVN, Vianna RO, Oliveira SA, Cavalcanti SMB. Diagnóstico de infecção primária pelo herpesvírus humano tipo 6B através da técnica de reação em cadeia da polimerase em crianças com doença exantemática [Diagnosis of human herpesvirus 6B primary infection by polymerase chain reaction in young children with exanthematic disease]. Rev Soc Bras Med Trop. 2011;44(3):306-8.

45. Carranza-Tamayo CO, Carvalho MSL, Bredt A, et al. Leishmaniose visceral autóctone em Brasília, Distrito Federal, Brasil [Autochthonous visceral leishmaniasis in Brasília, Federal District, Brazil]. Rev Soc Bras Med Trop. 2010;43(4):396-9.

46. Fraga TL, Brustoloni YM, Lima RB, et al. Polymerase chain reaction of peripheral blood as a tool for the diagnosis of visceral leishmanias; in children. Mem Inst Oswaldo Cruz. 2010;105(3):310-3.

47. Palmeira DCC, Carvalho AG, Rodrigues K, Couto JLA. Prevalê kia da infecção pelo Schistosoma mansoni em dois municípios de Alagoas [Prevalence of Schistosoma mansoni infe $n$ in vo municipalities of the State of Alagoas, Brazil]. Rev Soc Rras Me "op. 2010;43(3):313-7.

48. Pereira APB, FavreTC, Galvão AF, etal. The prevale e ofsch, tosom ois in school-aged children as an appropriate indicator ts prevalence in the community. Mem Inst Oswaldo Cruz. 2010;105(4):3. 9.

49. Basta PC, Rios DPG, Alves LCC, Sant'^ Coimbra Junior CEA. Estudo clinico-radiológico de cr nças e ado scents indígenas Suruí, Região Amazônica [Clinica and radiologi al study of Suruí indigenous children and adolescen. 4 mazor Region, Brazil]. Rev Soc Bras Med Trop. 2010; (6):719-?

50. Sales CMM, Figueiredo TAM, Z,ndor ue E, Maciel ELN. Análise espacial da tuberculose 2007 [Spatial analysis childruounaberculosis in the state of Espírito Santo, Brazil, $?$ J0 to 2007]. Soc Bras Med Trop. 2010;43(4):435-9.

51. Eymael D Cr GM, Tavares RG. Padronização do diagnóstico de Blastocystis hon is por diferentes técnicas de coloração [Stan arar tion of Blastocystis hominis diagnosis using different st hing ter Mlla Rev Soc Bras Med Trop. 2010;43(3):309-12.

52. Niš a' Dantas MC, de Abreu MT, de Melo CM, et al. Direct fluorescen, antibody assay and polymerase chain reaction for

In maction of Chlamydia trachomatis in patients with vernal ke toconjunctivitis. Clinics (Sao Paulo). 2011;66(12):2013-8.

53. A tins LMS, Wanke B, Lazéra MS, et al. Genotypes of Cryptococcus neorormans and Cryptococcus gattii as agents of endemic cryptococcosis in Teresina, Piauí (northeastern Brazil). Mem Inst
Oswaldo Cruz. 2011;106(6):725-30.

54. Costa CA, Façanha GP. Sorotipos virais de denque identificados em ciranças de Manaus, Estado do Amazc as, 2008 L. ngue virus serotypes in children of Manaus, State of mazonas, 200 . Rev Soc Bras Med Trop. 2011;44(2):249-51.

55. Miranzi SSC, Pereira LHM, Nune ar. rfil epruemiológico da hanseníase em um municípic srasileiro, no período de 2000 a 2006 [Epidemiological profile of rosy in a azilian municipality between 2000 and 2006], Rev Soc Bras i. d op. 2010;43(1):62-7.

56. Emiasegen SE, Nimzing L, Jogam hagenyi AY, Lekan R. Parvovirus B19 antibodies and correlc of infection in pregnant women attending an an natal clinic is entral Nigeria. Mem Inst Oswaldo Cruz. 2011;10f - $-: 2 \triangle 21$.

57. Gbotosho GO, SowunmI Happi CT, Okuboyejo TM. Plasmodium falcipar aametocyte carriage, sex ratios and asexual parasite rates in geriar cr.m. before and after a treatment protocol policy chans, istituting the use of artemisinin-based combination nerap s. Mem, st Oswaldo Cruz. 2011;106(6):685-90.

Ferna des Dereira CAP, Petrili AS, Pignatari ACC. Caracterização ecular de Pseudomonas aeruginosa resistentes a carba êumicos e produtoras de metalo- $\beta$-lactamase isoladas em hemoculturas de crianças e adolescentes com câncer [Molecular racterization of carbapenem-resistant and metallo-betalactamase-producing Pseudomonas aeruginosa isolated from blood cultures from children and teenagers with cancer]. Rev Soc Bras Med Trop. 2010;43(4):372-6.

59. Goud R, Gupta S, Neogi U, et al. Prevalência de Staphylococcus aureus resistente à meticilina e à vancomicina em comunidade no entorno de Bangalore, Índia do Sul [Community prevalence of methicillin and vancomycin resistant Staphylococcus aureus in and around Bangalore, southern India]. Rev Soc Bras Med Trop. 2011:44(3):309-12.

60. Aprile Mda M, Feferbaum R, Andreassa N, Leone C. Growth of very low birth weight infants fed with milk from a human milk bank selected according to the caloric and protein value. Clinics (Sao Paulo). 2010;65(8):751-6.

61. Lins MGM, Horowitz MR, Silva GAP, Motta MEFA. Teste de desencadeamento alimentar oral na confirmação diagnóstica da alergia à proteína do leite de vaca [Oral food challenge test to confirm the diagnosis of cow's milk allergy]. J Pediatr (Rio J). 2010;86(4):285-9.

62. Venancio SI, Escuder MML, Saldiva SRDM, Giugliani ERJ. A prática do aleitamento materno nas capitais brasileiras e Distrito Federal: situação atual e avanços [Breastfeeding practice in the Brazilian capital cities and the Federal District: current status and advances]. J Pediatr (Rio J). 2010;86(4):317-24.

63. Caetano MC, Ortiz TT, Silva SG, Souza Fl, Sarni RO. Complementary feeding: inappropriate practices in infants. J Pediatr (Rio J). 2010;86(3):196-201.

64. Silveira KB, Alves JF, Ferreira HS, Sawaya AL, Florêncio TM. Association between malnutrition in children living in slums, maternal nutritional 
status, and environmental factors. J Pediatr (Rio J). 2010;86(3):215-20.

65. Balaban G, Motta ME, Silva GA. Early weaning and other potential risk factors for overweight among preschool children. Clinics (Sao Paulo). 2010;65(2):181-7.

66. Nascimento VG, Bertoli CJ, Leone C. Ratio of weight to height gain: a useful tool for identifying children at risk of becoming overweight or obese at preschool age. Clinics (Sao Paulo). 2011;66(7):1223-6.

67. Pergher RN, Melo ME, Halpern A, Mancini MC; Liga de Obesidade Infantil. Is a diagnosis of metabolic syndrome applicable to children? J Pediatr (Rio J). 2010;86(2):101-8.

68. Samelli AG, Rabelo CM, Vespasiano AP. Development and analysis of a low-cost screening tool to identify and classify hearing loss in children: a proposal for developing countries. Clinics (Sao Paulo). 2011;66(11):1943-8.

69. Schochat E, Musiek FE, Alonso R, Ogata J. Effect of auditory training on the middle latency response in children with (central) auditory processing disorder. Braz J Med Biol Res. 2010;43(8):777-85.

70. Gonçalves IC, Wertzner HF, Samelli AG, Matas CG. Speech and nonspeech processing in children with phonological disorders: an electrophysiological study. Clinics (Sao Paulo). 2011;66(2):293-8.

71. Prudente COM, Barbosa MA, Porto CC. Relação entre a qualidade de vida de mães de crianças com paralisia cerebral e a função motora dos filhos, após dez meses de reabilitação [Relation between quality of life of mothers of children with cerebral palsy and the children's motor functioning, after ten months of rehabilitation]. Rev Latinoa Enferm. 2010;18(2):149-55.

72. Unlu E, Cevikol A, Bal B, et al. Multilevel botulinum toxin ty treatment for spasticity in children with cerebral palsy: a re study. Clinics (Sao Paulo). 2010;65(6):613-9.

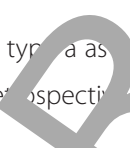

73. Bem RS, Muzzillo DA, Deguti MM, et al. Wilson's disease in southerm Brazil: a 40-year follow-up study. Clinics (Sao Paul 56(3):411-6.

74. Murphy CF, Schochat E. Generalization of ter poral order tection skill learning: two experimental studies of chi en with dysle a. Braz J Med Biol Res. 2010;43(4):359-66.

75. Nunes MDR, Dupas G. Independê cla da c nça com síndrome de Down: a experiência da famíli: Indepc, denc of children with Down syndrome: the experiences o ' 7 milies]. Re Latinoam Enferm. 2011;19(4):985-93.

76. Olandoski KP, Koch V, Tri ,-Rocha FE. al function in children with congenital neurogeni Jla ’r. Clinics (Sao Paulo). 2011;66(2):189-95.

77. Neves MCL, Tremeau F, Nicolato tal. Prejuízos no reconhecimento de emoções far als parentes de primeiro grau de portadores de autismo nã sấo ass â com o polimorfismo 5HTTLPR [Facial emotion recoy deficits in relatives of children with autism are not associated with S. TLPR]. Rev Bras Psiquiatr. 2011;33(3):261-7.

78. Pinhe, KAr, tho FMC, Quevedo LA, et al. Depressão paterna: episódio ir lar? [Paternal postpartum mood: bipolar episodes?] Rev Bras Psic iatr. 2011;33(3):283-6.

79. Zappitelli MC, Bordin IA, Hatch JP, et al. Lifetime psychopathology among the offspring of Bipolar I parents. Clinics (Sao Paulo).

\section{1;66(5):725-30}

80. Fávero-Nunes MA, Santos MA. Depressão e qualidade de vida em mães de crianças com transtornos invasivos do de nvolvimen [Depression and quality of life in mothers of childrer vith pervasive developmental disorders]. Rev Latinoam Enferm. 2010, 2(1):33-40.

81. Lin CH, Chen WL, Lin CM, et al. Predictors of P crim reaumsorions in the short - and long-term: a populatic -based stua, in Taiwan. Clinics (Sao Paulo). 2010;65(5):481-9.

82. Salum GA, Isolan LR, BosaVL, et al. Avaliacão multidimer . n etratamento da ansiedade em crianças e adole əntes. teórico, desenho, métodos e resultados prelimirares [Th $n$ ridimensional evaluation and treatment of anxiety in ildren and ac escents: rationale, design, methods and preliminary diris, Rev Bras Psicuiatr. 2011;33(2):181-95.

83. Turkiewicz G, Pinzon V, Lock Jeitlich-Bilyk B. Viabilidade, aceitação e eficác do tratamento familiar para anorexia nervosa em adolescentes: estr vacional no Brasil [Feasibility, acceptability, and et, iveness of family-based treatment for adolescer ano kia nerv a: an observational study conducted in Brazil] ev Bras quira 010;32(2):169-72.

84. Fermandes C, Januário JN, Cangussu CB, Macedo DL, Viana MB. ortalidade de ianças com doença falciforme: um estudo de bast vulacional [Mortality of children with sickle cell disease: a population, ydy]. J Pediatr (Rio J). 2010;86(4):279-84.

85. Menegassi M, Mello ED, Guimarães LR, et al. Ingestão alimentar e níveis $\mathrm{r}$ icos de ferro em crianças e adolescentes com transtorno de déf de atenção/hiperatividade [Food intake and serum levels of $\mathrm{m}$ in children and adolescents with attention-deficit/hyperactivity disorder]. Rev Bras Psiquiatr. 2010;32(2):132-8.

86. Sellami MH, Torjemane L, Arias AE, et al. Does minor histocompatibility antigen HA-1 disparity affect the occurrence of graft-versus-host disease in tunisian recipients of hematopoietic stem cells? Clinics (Sao Paulo). 2010;65(11):1099-103.

87. Bortolini GA, Vitolo MR. Relação entre deficiência de ferro e anemia em crianças de até 4 anos de idade [Relationship between iron deficiency and anemia in children younger than 4 years]. J Pediatr (Rio J). 2010;86(6):488-92.

88. Reis MCG, Nakano AMS, Silva IA, Gomes FA, Pereira MJB. Prevalência de anemia em crianças de 3 a 12 meses de vida em um serviço de saúde de Ribeirão Preto, SP, Brasil [Prevalence of anemia in children three to 12 months old in a health service in Ribeirão Preto, SP, Brazil]. Rev Latinoam Enferm. 2010;18(4):792-9.

89. Dumaresq DMH, Vasconcelos RC, Guimarães SB, et al. Efeitos metabólicos e oxidativos do sevoflurano e do propofol em crianças portadoras de cardiopatia congênita submetidas à cirurgia [Metabolic and oxidative effects of sevoflurane and propofol in children undergoing surgery for congenital heart disease]. Acta Cir Bras. 2011;26(supl 1):66-71.

90. Tedde ML, Campos JR, Das-Neves-Pereira JC, Abrão FC, Jatene FB. The search for stability: bar displacement in three series of pectus excavatum patients treated with the Nuss technique. Clinics (Sao 
Paulo). 2011;66(10):1743-6.

91. Kayiran SM, Dindar A, Gurakan B. An evaluation of children with Kawasaki disease in Istanbul: a retrospective follow-up study. Clinics (Sao Paulo). 2010;65(12):1261-5.

92. Orlando JL, Caldas JG, Campos HG, Nishinari K, Wolosker N. Outpatient percutaneous treatment of deep venous malformations using pure ethanol at low doses under local anesthesia. Clinics (Sao Paulo). 2010;65(9):837-40

93. Vanderlei LC, Pastre CM, Freitas Júnior IF, Godoy MF. Analysis of cardiac autonomic modulation in obese and eutrophic children. Clinics (Sao Paulo). 2010;65(8):789-92

94. Guimarães H, Rocha G, Pissarra S, et al. Respiratory outcomes and atopy in school-age children who were preterm at birth, with and without bronchopulmonary dysplasia. Clinics (Sao Paulo). 2011;66(3):425-30.

95. Munhoz AS, Adde FV, Nakaie CMA, et al. Oxigenoterapia domiciliar prolongada em crianças e adolescentes: uma análise do uso clínico e de custos de um programa assistencial [Long-term home oxygen therapy in children and adolescents: analysis of clinical use and costs of a home care program]. J Pediatr (Rio J). 2011;87(1):13-8.

96. Soeiro Ade M, Ruppert AD, Canzian M, et al. Demographic, etiological, and histological pulmonary analysis of patients wit' acute respiratory failure: a study of 19 years of autopsies. Clinics ao Paulo). 2011;66(7):1193-7.

97. Cicogna EC, Nascimento LC, de Lima RAG Crianças e ad sscente com câncer: experiências com a quimioterapia [C. tren id adolescents with cancer: experiences with chemotherap, Rev Latinoam Enferm. 2010;18(5):864-72.

98. Estrozi B, Bacchi CE. Neuroendocrine ors in gastroenteropancreatic tract: a clinicopathological uation of 773 cases. Clinics (Sao Paulo). 2011;66(10):1671-5.

99. Gualco G, Klumb CE, Barber GN, Wacchi CE. Pediatric lymphomas in Brazil. Clinics (Sao P ro). 2010;65 ?):1267-77.

100. Pan R, Marques AR, Costa Júnior $\Lambda$ Nascimento C. Caracterização das internações hospitalares de ncas adolescentes com neoplasias [Characterizat of the of ofitalization of children and adolescents with cance Rev Launoam =nerm. 2011;19(6):1413-20.

101. Tamashiro MS, Aikawa NL Campos LN et al. Discrimination of acute lymphoblastic leuke, from,-remic-onset juvenile idiopathic arthritis at dis se onset. CI. (Sao Paulo). 2011;66(10):1665-9.

102. Vaisman F sur $\sim$ DA, Pessoa CH, et al. Prognostic factors of a good response to in therapy in children and adolescents with diffe rtla $d$ thyroid cancer. Clinics (Sao Paulo). 2011;66(2):281-6.

103. Y' bao C, 7 ou w/eihong $S$, et al. Cloning, expression, and analysis of th up 2 allergen from Dermatophagoides farinae from China. An Acad D Cienc. 2010;82(4):941-51.

74. Sory ancevich JC, Borges MS, et al. Anaphylaxis in Latin America: 7 port of the online Latin American survey on anaphylaxis (OLASA). a ics (Sao Paulo). 2011;66(6):943-7.

105. Macếdo SF, Araújo MFM, Marinho NPB, et al. Fatores de risco para diabetes mellitus tipo 2 em crianças [Risk factors for type 2 diabetes mellitus in children]. Rev Latinoam Enferm. 2010;18(5):936-42.

106. Carvalho FL, Mezzacappa MA, Calil R, Machado HC. Incidência e fatores de risco para a extubação aciden em uma nidade de terapia intensiva neonatal [Incidence anc risk factors of ccidental extubation in a neonatal intensive care nit]. J Ped (r (Rio J). 2010;86(3):189-95

107. Costa GA, Delgado AF, Ferraro A jkay TS. App tion of the pediatric risk of mortality (PRISM) score an determin on of mortality risk factors in a tertiary pediatric intensive nit. Clinics (Sao Paulo). 2010;65(11):1087-92.

108. Vendrusculo TM, Barlieiro Ch F nevarría-Guanilo ME, Farina Junior JA, Rossi LA. Qu naduras em nbiente doméstico: características e circunstânc do didente [Burns in the domestic environment: characteristics and circu tances of accidents]. Rev Latinoam Enferm $\sim 10 \cdot 18(3): 444-51$

109. Shorogh Arba ahbakhsh F, Sheikhvatan M, Abbasi A. Efeitos peroperatón da premedicação oral de midazolam em crianças abmi idas a tamento de pele por laser: estudo duplo-cego rande IIzan controlado [Perioperative effects of oral midazolam nedication in children undergoing skin laser treatment: a doub linded randomized placebo-controlled trial]. Acta Cir Bras. 2011;26(4):303-9

110. nn TW, Yang ZG, Dong ZH, et al. Earthquake-related pelvic crush fracture vs. non-earthquake fracture on digital radiography and MDCT: a comparative study. Clinics (Sao Paulo). 2011;66(4):629-34.

11. Chu ZG, Yang ZG, Dong ZH, et al. Comparative study of earthquakerelated and non-earthquake-related head traumas using multidetector computed tomography. Clinics (Sao Paulo). 2011;66(10):1735-42.

112. Ribeiro RR, Santos-Ribeiro KD, Guerra-Junior G, Barros-Filho Ade A. Comparison of bone quantity by ultrasound measurements of phalanges between white and black children living in Paraná, Brazil, with Europeans. Braz J Med Biol Res. 2010;43(10):976-81.

113. Taveira AT, Pereira FA, Fernandes Ml, et al. Longitudinal evaluation of hepatic osteodystrophy in children and adolescents with chronic cholestatic liver disease. Braz J Med Biol Res. 2010;43(11):1127-34.

114. Castro-Antunes MM, Crovella S, Brandão LA, et al. Frequency distribution of HLA DQ2 and DQ8 in celiac patients and first-degree relatives in Recife, northeastern Brazil. Clinics (Sao Paulo). 2011;66(2):227-31.

115. Gonzales ACS, Vieira SMG, Maurer RL, Silva FAA, Silveira TR. Utilidade da concentração da elastase-1 fecal monoclonal na avaliação da função pancreática nos pacientes com fibrose cística [Use of monoclonal faecal elastase-1 concentration for pancreatic status assessment in cystic fibrosis patients]. J Pediatr (Rio J). 2011;87(2):157-62.

116. Hong WD, Dong LM, Jiang ZC, Zhu QH, Jin SQ. Prediction of large esophageal varices in cirrhotic patients using classification and regression tree analysis. Clinics (Sao Paulo). 2011;66(1):119-24.

117. Hua-Li Z, Shi-Chao X, De-Shen T, Dong L, Hua-Feng L. Seasonal distribution of active systemic lupus erythematosus and its correlation with meteorological factors. Clinics (Sao Paulo). 2011;66(6):1009-13. 
118. Dutra RA, Perez-Bóscollo AC, Melo EC, Cruvinel JC. Importância clínica e prevalência de microlititíase testicular em pacientes pediátricos [Clinical importance and prevalence of testicular microlithiasis in pediatric patients]. Acta Cir Bras. 2011;26(5):387-90.

119. Medina Arias N, Ferriani MGC. Factores protectores de las familias para prevenir el consumo de drogas en un municipio de Colombia [Protective factors for preventing the use of drugs in the families of a Colombia locality]. Rev Latinoam Enferm. 2010;18(spe):504-12.

120. Cid-Monckton P, Pedrão LJ. Factores familiares protectors y de riesgo relacionados al consumo de drogas en adolescentes [Protective and family risk factors related to adolescent drug use]. Rev Latinoam Enferm. 2011;19(spe):738-45.

121. Mattar ACV, Gomes EN, Adde FV, Leone C, Rodrigues JC. Comparação entre o método clássico de Gibson e Cooke e o teste da condutividade no suor em pacientes com e sem fibrose cística [Comparison between classic Gibson and Cooke technique and sweat conductivity test in patients with and without cystic fibrosis]. J Pediatr (Rio J). 2010;86(2):109-14.

122. Stollar F, Adde FV, Cunha MT, Leone C, Rodrigues JC. ShwachmanKulczycki score still useful to monitor cystic fibrosis severity. Clinics (Sao Paulo). 2011;66(6):979-83.

123. Bousso RS, Serafim TS, Misko MD. Histórias de vida de familiares de crianças com doenças graves: relação entre religião, doença e morte [The relationship between religion, illness and death in life histories of family members of children with life-threatening diseases]. Rev Latinoam Enferm. 2010;18(2):156-62.

124. Dutra RL, Pieri Pde C, Teixeira AC, et al. Detection of deletions at 7q11.23 in Williams-Beuren syndrome by polymorphic arkerClinics (Sao Paulo). 2011;66(6):959-64.

125. Eren SH, Demirel Y, Ugurlu S, et al. Mushroom poisoning: retrosp ive analysis of 294 cases. Clinics (Sao Paulo). 2010;65(5):491-6.

126. Ferrer AP, Sucupira AC, Grisi SJ. Causes of hor tion among children ages zero to nine years old in the $c y$ of São Pa Bazil. Clinics (Sao Paulo). 2010;65(1):35-44

127. Fomin AB, Pastorino AC, Kim CA, et al. DiGeorgo undrom a not so rare disease. Clinics (Sao Paulo). 201 $05(9): 86{ }^{5}$

128. Luque ALF, Lima CMG, Carvalhaes AABL, Thete Lr, Parada CMGL. Avaliação da atenção ao recém-nas to de risco la perspectiva de uma política pública de saúde la vationun fure for at-risk newborns from the perspective of sublic healtr. vicy]. Rev Latinoam Enferm. 2011;19(2):293-300

129. Nascimento LC, Strabelli BS, Alr da FCQG, et al. O manejo da dor em crianças, n pos peratório tardio de cirurgia cardíaca, pelos profissionaic e enfer agu na ótica das mães [Mothers' view on late postopera. in management by the nursing team in children after cardiac surgery, pv Latinoam Enferm. 2010;18(4):709-15.

130. Nomá Carva odeS, Kara-José N. Why are there defaulters in eye health pl of Clinics (Sao Paulo). 2011;66(9):1585-9.

131. Noreña Peña Cibanal Juan L. A experiência de crianças hospitalizadas sobre sua interação com os profissionais de enfermagem [The experience of hospitalized children regarding their interactions with nursing professionals]. Rev Latinoam Enferm. 2011;19(6):1429-36.

132. Wang PC, Chang YH, Chuang LJ, Su HF, Li CY. Incidence and recurrence of acute otitis media in Taiwan's pediatric populatio Clinics Paulo). 2011;66(3):395-9.

133.Zambrano-Sánchez E, Martínez-Wbaldo MC, Poblano Frequên de fatores de risco para dificuldade de a rur. rem créescolares com baixo nível socioeconômi , na Cidade 'o México [Risk factor frequency for learning disabilitic. Llow soci zconomic level preschool children in Mexico city]. Rev Lu r am Enferm. 2010;18(5):998-1004.

134. Areias CM, Sampaio-Maia B, Guimarae elo P, Andrade D. Caries in Portuguese children wi' Down syna me. Clinics (Sao Paulo). 2011;66(7):1183-6.

135. Carrillo C, Vizeu H, Soares-Júnior LA, M M, Filho VO. Dental approach in the pediatric or Inav patient: characteristics of the population treated at the dentis unit an ratric oncology brazilian teaching hospital. Clinics (Sao Pà ') 2010;65(6):569-73.

136. Lima CM, Palı PF, Zà tti ML, Parada CMGL. Experiências do familia em rel ao a uidado com a saúde bucal de crianças [Exrarien f family members regarding the oral health care of Idren]. Rev La vam Enferm. 2011;19(1):171-8.

2. Mom J, Bachiega JC, Guedes CC, Laranja LT, Bussadori SK. Association hetween halitosis and mouth breathing in children. Sinics (Sao Paulo). 2011;66(6):939-42.

17 . Perinet G, Contardo L, Biasati AS, Perdoni L, Castaldo A. Dental mal clusion and body posture in young subjects: a multiple luyression study. Clinics (Sao Paulo). 2010;65(7):689-95.

Souza MA, Soares Junior LA, Santos MA, Vaisbich MH. Dental abnormalities and oral health in patients with Hypophosphatemic rickets. Clinics (Sao Paulo). 2010;65(10):1023-6.

140. Cunha Filho JF, Gonçalves II, Guimarães SB, et al. Pré-tratamento com L-alanil-glutamina atenua a resposta inflamatória aguda em crianças submetidas à palatoplastia [L-alanyl-glutamine pretreatment attenuates acute inflammatory response in children submitted to palatoplasty]. Acta Cir Bras. 2011;26(supl 1):72-6.

Sources of funding: None

Conflict of interest: None

Date of first submission: July 7, 2012

Last received: August 17, 2012

Accepted: August 22, 2012

\section{Address for correspondence:}

Maurício Rocha-e-Silva

Rua Doutor Ovídio Pires de Campos, 225 - 6o andar

Cerqueira César — São Paulo (SP) — Brasil

CEP 05403-010

Tel. (+55 11) 2661-6235

E-mail: mauricio.silva@hc.fm.usp.br 